Archaeological Journal

\title{
Observations On The Supposed Sword Of Sir Hugh De Morville
}

\section{R. S. Ferguson M.A., F.S.A.}

To cite this article: R. S. Ferguson M.A., F.S.A. (1880) Observations On The Supposed Sword Of Sir Hugh De Morville, Archaeological Journal, 37:1, 99-101, DOI: 10.1080/00665983.1880.10851928

To link to this article: http://dx.doi.org/10.1080/00665983.1880.10851928

册 Published online: 14 Jul 2014.

Submit your article to this journal

Q View related articles $₫$ 


\title{
OBSERVATIONS ON THE SUPPOSED SWORD OF SIR HUGH DE MORVILLE.
}

\author{
By R. S. FERGUSON, M.A., F.S.A.
}

Some little time ago I was written to about a story that at Brayton Hall in Cumberland is preserved the sword with which Sir Hugh de Morville killed Sir Thomas a Beckett, ${ }^{1}$ or rather with which Sir Hugh de Morville kept guard in the transept while the murder was being committed. The story goes on to say that the sword was formurly in Carlisle Cathedral, suspended over the grave of Hugh de Morville.

This fable, in its main features, has long been familiar to me. The sword in question is at Brayton Hall in Cumberland, the seat of Sir Wilfred Lawson, who tells me that Dean Stanley was here many years ago, and that he considered the story about the sword to be all nonsense. Sir Wilfred does not know how the tale ever got afloat. He says the sword is in the hand of an old figure of a man in armour, which has been in the house as long as he can recollect.

The story is worth examination, for it is connected with a gross and misleading error in the early history of Cumberland, which had its origin in the Chronicon Cumbrice, a brief chronicle formerly preserved in the Priory of Wetheral, and printed by Dugdale in the Monasticon. Mr. Hodgson Hinde, writing on the Early History of Cumberland in the Archceological Journal, vol. xvi, p. 234, and exposing the many inaccuracies of this Chronicon Cumbrice, says :- "Another mistake is the identification of Hugh cle Morville, lord of the barony of Burgh, with his more notorious namesake, the murderer of Thomas a Becket. Hugh was a common name in the Morville family, as appears by various clocuments in which we meet with the name of Hugh de Morville, at dates and under circumstances which show that it could be neither of the above. IIugh de Morville of Burgh was the grandson of Simon de Morville, who was probably the brother, and certainly the contemporary, of Becket's assassin. The former survived to the reign of John; whereas the latter is stated by all the biographers of the saint to have died at Jerusalem, whither he had gone on a pilgrimage in expiation of his offence, and to have been buried in front of the Temple within three years of the murler. $\mathrm{He}$ was lord of Westmoreland, and of Knaresborongh in Yorkshire, at the same time that Burgh was possessed by Simon, the grandfather of his namesake." This error was angmented and amplified in the much quoted manuscript history of Cumberland by John Denton of Cardew, written probably in the time of Queen Elizabeth, and brought down by

1 Murray's Handbook for Kent and Sussex (1858), p. 168. 
Mr. Denton to 1610 . He there says, writing of the lords of the Barony of Burgh (Burgh on Sands) in Cumberland :-

"After W" $\mathrm{W}^{\mathrm{m}}$ Engayne succeeded $\mathrm{S}^{\mathrm{r}}$ Hugh Morvill, as son and Heir of Ada sole daur \& Heir of the $\mathrm{s}^{\mathrm{d}}$ William. In the time of Hen: $2^{\mathrm{d}}$ this $\mathrm{S}^{\mathrm{r}}$ Hugh Morvill was of great possessions in Cumberland he was Lord of Burgh Barony Lassenby and Ishall. In Westmorland of Temple Sowerby Hofton \&c. and about Wharton he had divers Lancls. The great mountain Hugh Seat Morvill was called after him. $\mathrm{He}$ was one of the four Rnights who killed $S^{t}$ Thomas a Becket Archbishop of Canterbury. After which Deed he came to great misery, He gave therefore the Rectory of Burgh to the Abley of Folme Cultram which the Bishops of Carlisle Bernard Hugh and Walter did appropriate to the Monks. The sword that killed $S^{t}$ Thrmas was at Ishall in my father's time and since remaineth with the house of Arundel. He was greatly hated of the Churchmen of his time, therefore they wrote many things to his Dishonour, hardly to be creclited which I omitt. After great Repentance he died \& left two daughters his Heirss Johan wife to Richard Worun or Gerun (Gernon) \& Ada wife first to Richard Lucy $2^{\text {nd }}$ to Thomas Multon and $3^{\mathrm{d}}$ to $\mathrm{W}^{\mathrm{m}}$ Lord Furnival."

As Ishall or Isel belonged to the Hugh de Morville, who was lord of Burgh, it is clear that the sword seen there by Denton's father would do so too, and that Denton has libelled the sword just as the Chronicon Cumbrice libelled its owner.

Now, as Denton says that the belibelled sword "since remaineth with the house of Arundel," how comes it, that a sword with a similar history, is at Brayton? As Ishall or Isel was the original seat of the Lawsons in Cumberland, it is easy to account for the legend shifting from one house to the other, and the sword that is at Brayton may be the one that Denton's father saw at Isel. But I am rather inclined to think it came from elsewhere.

In Aikton churchyard, Cumberland, is a fine monumental slab, which has on it, where a cross is usually found, a large two-handed sword, about three feet five inches long, with a cross piece eight inches long, the quillons being slightly bent towards the point of the sword. The sword and foliage carved round it are in high relief, a moulding runs along the edge of the stone, and on it at intervals occurs the dog tooth ornament. The sides of the slab are ornamented with foliage, and its date seems to be late XIIIth century. Be that as it may, the local legend is that this is the tomb of Sir Hugh de Morville, that this is the sword with which he killed a Becket, that he resided at Down Hall in the parish of Aikton, and that his sword was kept there until it was taken to Brayton. We come round again to the same error. The Sir Hugh de Morville, who owned Aikton and Down Hall, and left them to his daughter Johan Gernon, was the same man with the innocent Lord of Burgh, so that this sword, too, has been wronged.

I think it very probable that within the last 150 years some sword has been taken from Aikton church or Down Hall to Brayton Hall, more probable than that the sword now at Brayton is the one that Denton's father saw at Ishall. But, wherever that Brayton sword came from, sure am I that it is not the one with which Hugh de Morville of Westmoreland and Knaresborough kept the transept in Canterbury Cathedral while Thomas a Becket was done to death. 
Not having seen the sword now at Brayton, I cannot say whether it has any claim to be of the date of the Hugh de Morville Lord of Burgh.

As for the connection of the sword with Carlisle Cathedral, it is clear that if the murderer was buried before the Temple at Jerusalem, he could not be also buried in Carlisle Cathedral, and the story of his sword having been there falls to the ground. A Sir Hugh de Morville may have been buried in Carlisle Cathedral, though there is no record of such burial, A Sir Hugh de Morvillo is buried in Great Salkeld church in Cumberland, and he is neither of the two I have been writing about.

Since writing the above remarks, Sir Wilfred Lawson has kindly sent me the sword for exhibition at the Institute. It turns out to be a basket-hilted broadsword, the blade is 2 feet $8 \frac{1}{2}$ inches long and the tang $6 \frac{1}{2}$ inches. The blade has on it a German motto-

"Gott bewahrt die aufrecht Schotten."

I have also, by accident, lit upon the following passage in "the Ancient Family of Carlisle," by the late Mr. Nicholas Carlisle, which explains what is the figure of a man in armour, mentioned by Sir W. Lawson. Writing of one Thomas Carlyle, an organ-maker and carver in Carlisle, who died in 1816, aged 83, Mr. Nicholas Carlisle says, "But his chief performance was finished in his sixty-seventh year (i.e., 1801), when most men are suffering under the infirmities of age. This was a statue, as large as life of Sir Hugh de Morville, which he made for the late Sir Wilfred Lawson, Bart., of Brayton House in Cumberland. It is cloathed in armour, and holds the very sword with which that celebrated knight assisted in delivering the country from Thomas a Becket the insolent Primate of Canterbury."

This does not explain what reason the Sir Wilfred Lawson of 1801 had for connecting the broadsword exhibited at the Institute with Sir Hugh de Morville. Did he find it at Brayton? did he get it from Down Hall or Aikton? or did Thomas Carlyle get it for his patron from Carlisle Cathedral, where Thomas Carlyle did vast mischief, being the perpetrator of the ugly and doomed Bishop's throne and pews. The broadsword was very likely left in the cathedral by some of the Highlanders who were imprisoned there in December, 1745. It is probably not much earlier in date. 